Editorial

\title{
Spatial Underpinnings of Social Inequalities: A Vicious Circles of Segregation Approach
}

\author{
Tiit Tammaru ${ }^{1, *}$, David Knapp ${ }^{1}$, Siiri Silm ${ }^{1}$, Maarten van Ham ${ }^{2,3}$ and Frank Witlox ${ }^{4,1}$ \\ ${ }^{1}$ Department of Geography, Institute of Ecology and Earth Sciences, Faculty of Science and Technology, University of Tartu, \\ 54014 Tartu, Estonia; Emails: tiit.tammaru@ut.ee (T.T.), david.knapp@ut.ee (D.K.), siiri.silm@ut.ee (S.S.), \\ frank.witlox@ugent.be (F.W.) \\ ${ }^{2}$ Department of Urbanism, Delft University of Technology, 2628 Delft, The Netherlands; Email: m.vanham@tudelft.nl \\ ${ }^{3}$ School of Geography \& Sustainable Development, University of St. Andrews, St. Andrews, KY169AL, UK \\ ${ }^{4}$ Department of Geography, Ghent University, S8 9000 Gent, Belgium \\ * Corresponding author
}

Submitted: 6 April 2021 | Published: 13 May 2021

\begin{abstract}
A paradigm shift is taking place in spatial segregation research. At the heart of this shift is the understanding of the connectedness of spatial segregation in different life domains and the availability of new datasets that allow for more detailed studies on these connections. In this thematic issue on spatial underpinnings of social inequalities we will outline the foundations of the 'vicious circles of segregation' framework to shed new light on questions such as: What is the role of residential neighbourhoods in urban inequalities in contemporary cities? Have residential neighbourhoods lost their importance in structuring daily lives since important part of social interaction takes place elsewhere? How is residential segregation related to inequalities in other important life domains, in schools, at work and during leisure time? The vicious circles of segregation framework builds on the traditional approaches to spatial segregation, as well as on the emerging new research undertaken within the 'activity space approach' and 'longitudinal approach' to segregation. The articles in this thematic issue improve our understanding of how spatial segregation is transmitted from one life domain to another as people sort into residential neighbourhoods, schools, workplace and leisure time activity sites, and gain contextual effects by getting exposed to and interacting with other people in them.
\end{abstract}

\section{Keywords}

activity space; discrimination; housing; inequality; life domains; segregation; social networks

\section{Issue}

This editorial is part of the issue "Vicious Circle of Segregation: Understanding the Connectedness of Spatial Inequality across Generations and Life Domains" edited by Tiit Tammaru (University of Tartu, Estonia), Siiri Silm (University of Tartu, Estonia), Frank Witlox (Ghent University, Belgium), Maarten van Ham (Delft University of Technology, The Netherlands) and Madli-Johanna Maidla (University of Tartu, Estonia).

(C) 2021 by the authors; licensee Cogitatio (Lisbon, Portugal). This editorial is licensed under a Creative Commons Attribution 4.0 International License (CC BY).

\section{Paradigm Shift: From Residential Segregation to a Multi-Domain Understanding of Segregation}

Large cities continue to attract people and jobs despite decade-long efforts to achieve more inclusive regional development. How inclusive are large cities themselves for people clustering in them? Do large cities provide opportunities for all, or do they provide opportunities on a selective basis to selected groups of people? What is the role of residential neighbourhoods in facilitating social and spatial inclusion? Have other spatial settings, such as schools, workplaces, or free time activity places, become the main arenas that shape how unequal or inclusive contemporary cities are?

This thematic issue addresses these and many other related questions in eleven articles, and it delivers three 
key messages to the ongoing discussions on the spatial underpinnings of inequalities and social inclusion in contemporary cities. First, it is short-sighted to downplay the importance of residential neighbourhoods for understanding how spatial inequalities are produced and reproduced. Second, a vicious circle of segregation framework helps to shed new light on how spatial inequalities in different life domains are connected to each other, encompassing the whole activity space of people-residential neighbourhoods, schools, workplaces and leisure time activity sites. Third, bringing together research from longitudinal studies on individual life courses and across generations with research from daily activity spaces anchored around homes provides the key for understanding how urban social and spatial inequalities form, how to break the vicious circles of inequality and segregation, and what might be the roadmap towards more socially and spatially inclusive cities.

Research on spatial inequalities and exclusion has mainly focused on residential segregation (Booth, 1888; E. W. Burgess, 1925; Krysan \& Crowder, 2017; Maloutas \& Fujita, 2012; Musterd, 2005; Musterd \& Ostendorf, 1998; Peach, 1996; Schelling, 1971; Tammaru, van Ham, Marcińczak, \& Musterd, 2016; van Ham, Tammaru, Ubarevičienè, \& Janssen, 2021). Residential segregation, defined as an uneven distribution of population groups across urban neighbourhoods, is generally understood as a function of income inequality, preferences and discrimination. Although income inequality is often seen as the prime cause for the spatial inequality between population groups, for residential segregation to occur, housing preferences matter as well. Segregation levels rise if high-income households seek housing in attractive parts of the city, such as regenerated inner-city neighbourhoods, pushing house prices in those neighbourhoods beyond the reach of lower-income households (Pastak, 2021). Some forms of discrimination tend to operate in housing markets as well, even when explicit discrimination is outlawed, stemming from subtle mechanisms that range from the selection of renters by landlords through to which neighbourhoods are included in the consideration set by renters (Krysan \& Crowder, 2017).

Residential sorting is a household-level process (Rossi, 1955) and, since people tend to find partners similar to themselves (Kalmijn, 1991), residential segregation by income or social status is reinforced by demographic processes of family formation. Dual-earner households with two higher incomes drive urban spatial inequalities through their behaviour in the housing market, as they have the purchasing power to buy in the most attractive neighbourhoods. Lower-income households have much less choice and less financial credibility with banks and, as a result, they rent or buy in low-cost neighbourhoods (Gonalons-Pons \& Schwartz, 2017). Since there is some overlap between social groups and ethnic groups in terms of incomes, a triple inequality-social, ethnic and spatial-or 'eth-class' segregation tends to emerge in multi-ethnic cities (R. Andersson \& Kährik, 2016). In his pioneering study, Peach (1980) took an explicit interest in the links between family formation and residential segregation. He showed that ethnic minorities living in a co-ethnic union live in more segregated neighbourhoods compared to ethnic minorities living in a mixed ethnic union with members of the native majority population.

The considerations of households that produce and reproduce spatial inequalities go beyond financial resources at hand. The search for a home also relates to other important decisions facing families, including where to school children and how to obtain easy access to jobs and other urban amenities. In other words, the choice of where to live relates to the linked lives of family members and to the needs related to the daily activity space of all family members (Coulter, van Ham, \& Findlay, 2015; Järv, Müürisepp, Ahas, Derudder, \& Witlox, 2015; Silm et al., 2021; Silm \& Ahas, 2014). In addition, the choice of housing options is influenced by social network ties and their locations (Krysan \& Crowder, 2017). Hence, the long-term residential decisions are tightly related to the expectations families have towards schools and other important daily activity sites. Different neighbourhood characteristics tend to be considered jointly; the overall reputation of neighbourhoods as places to live and raise children is especially important in the home search of families (Bernelius, Huilla, \& Lobato, 2021; Nieuwenhuis \& Xu, 2021).

The study by Rivkin (1994) was the first to measure whether segregation in residential neighbourhoods and schools are related. Based on the analysis of US census data from 1968, 1980 and 1988, he found that schools are highly segregated primarily because of high levels of residential segregation. School segregation is largely driven by the fact that children generally attend nearby schools and, as neighbourhoods are relatively homogeneous in composition, schools are too (Bernelius \& Vilkama, 2019; Oberti \& Savina, 2019; Rich, Candipan, \& Owens, 2021). Ellis, Wright, and Parks (2004) established that there is also a strong connection between levels of residential and workplace segregation. Based on census data from 1990 in Los Angeles, they found that residential segregation accounts for about half of workplace segregation. In short, research on residential segregation has gradually established strong links with segregation in other important domains of daily life: schools and workplaces. Neighbourhood reputation is important in residential sorting, and homes are an important anchor point for other daily activities, shaping access both to schools (Nieuwenhuis \& Xu, 2021), jobs (Delmelle, Nilsson, \& Adu, 2021) and leisure time activities (Kukk, van Ham, \& Tammaru, 2019; Mooses, Silm, \& Ahas, 2016; Silm \& Ahas, 2014).

\section{Conceptual Foundations of the Vicious Circle of Segregation}

The pioneering studies on the connectedness of residential segregation with family formation (Peach, 1980), 
school segregation (Rivkin, 1994) and workplace segregation (Ellis et al., 2004), paved the way for a paradigm shift in research on the spatial underpinnings of inequality and inclusion in cities, from residential segregation to a multi-domain understanding of segregation. This paradigm shift was further supported by the availability of individual-level, longitudinal, relational and geocoded register data covering full populations. While early pioneering studies provided "photo-like" snapshots on levels of and changes in segregation, longitudinal studies (e.g., Manley, van Ham, \& Hedman, 2020; Musterd, Ostendorf, \& de Vos, 2003; Strömgren et al., 2014; Tammaru, Strömgren, Stjernström, \& Lindgren, 2010; Torpan, Sinitsyna, Kährik, Kauppinen, \& Tammaru, 2020; Vogiazides \& Chihaya, 2020) allow for a "video-like" following of people across time and space, connecting their behaviour in school, residential and work environments, and connecting family members, neighbours, schoolmates and co-workers with each other.

These longitudinal empirical studies led to the first attempts to conceptualize the connectedness of segregation in different spatial settings. Tammaru et al. (2010) introduced the term 'domains' for studying the contextual effects of residential neighbourhoods and workplaces on migrant incomes. Silm and Ahas (2014) proposed an 'activity space approach' for analysing links between different 'activity sites' by focusing on segregation in residential neighbourhoods and other out-ofhome daily activities. Van Ham and Tammaru (2016) elaborated the 'domains approach' for investigating the linkages and interactions between different domains over time. Boterman and Musterd (2017) used the notion of 'cocooning' to explain segregation at places of work and residence, and in transport. Park and Kwan (2017) proposed the term 'multi-contextual segregation' for under- standing how immigrants and members of the host population sort into various daily activity sites, anchored around home and work. Tammaru, Kallas, and Eamets (2017) introduced the term 'vicious circle of segregation' to show how spatial inequalities and segregation are systematically produced and reproduced in different life domains, in residential neighbourhoods, workplaces and schools. Finally, van Ham, Tammaru, and Janssen (2018) developed the 'vicious circles of segregation' framework by explaining that feedback loops connect segregation in different life domains over the life course and across generations.

Within a vicious circles of segregation framework, a city could be understood as a set of different life domains where spatial inequalities are produced and reproduced, including the residential domain, school domain and work domain (Figure 1). Domains are the sum of activity sites; all residential neighbourhoods in the city form the residential domain, all schools form the school domain, and all workplaces form the work domain. If high-income households sort into certain residential neighbourhoods (i.e., activity sites), they drive up segregation in the residential domain. When kids from affluent families attend certain schools, they drive up segregation in the school domain. When people with certain skills are sorted into certain workplaces, they drive up segregation in the work domain. Indices of segregation can be computed for each domain to compare levels of segregation between them (Silm, Ahas, \& Mooses, 2018; Toomet, Silm, Saluveer, Ahas, \& Tammaru, 2015).

The aim of this thematic issue is to contribute to the ongoing paradigm shift in research on spatial inequalities in the city by shedding new light on segregation as a multi-domain process, its drivers and consequences, and how segregation may be passed from generation

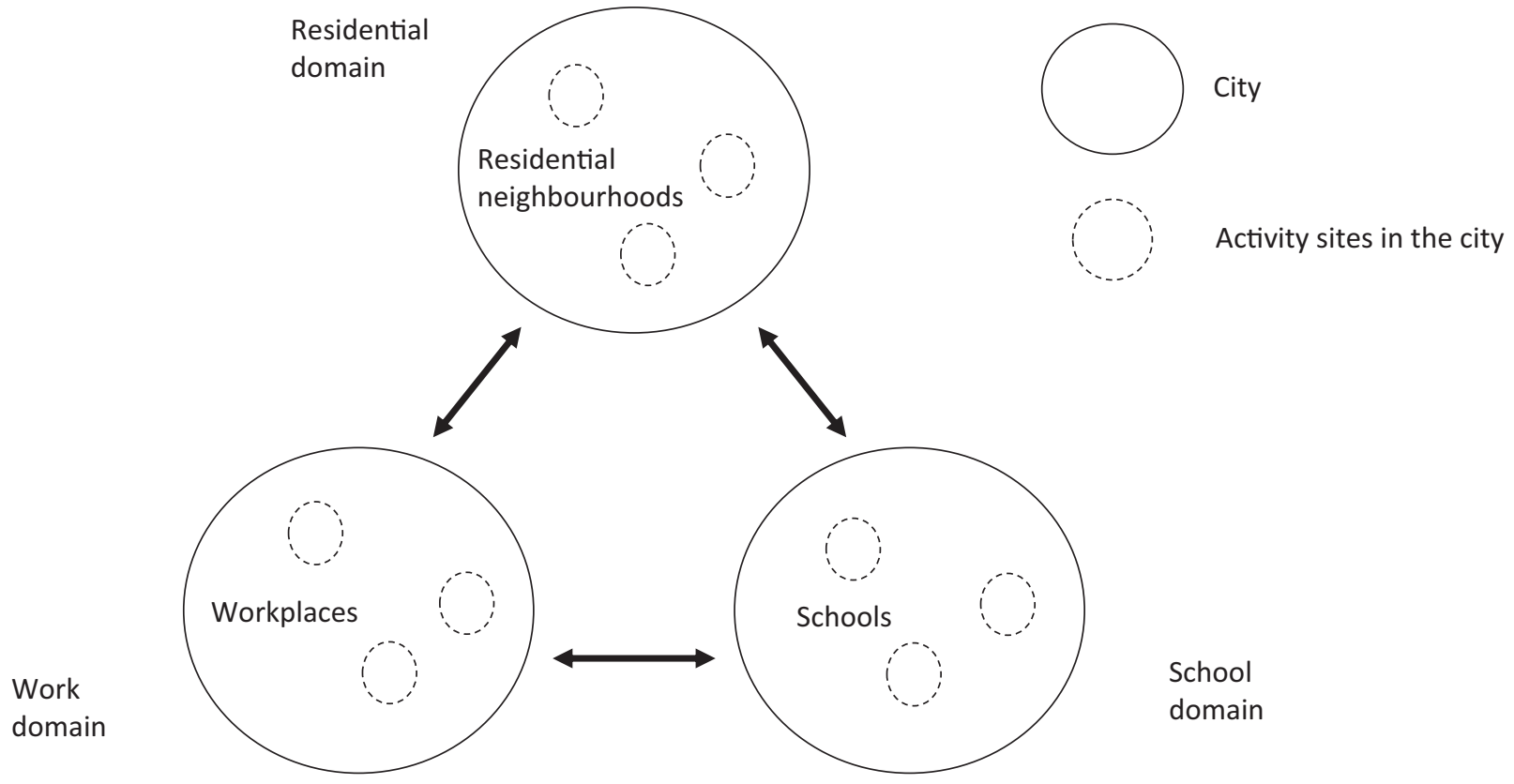

Figure 1. The connections between spatial inequalities in different life domains. 
to generation as people sort into concrete activity sites. By following the 'domains approach' by van Ham and Tammaru (2016) and the 'activity space approach' by Silm and Ahas (2014), we develop further the 'vicious circles of segregation' framework (Tammaru et al., 2017; van Ham et al., 2018). The production and reproduction of inequalities and segregation in different life domains emerges as a result of (1) the sorting of people into concrete activity sites by buying or renting a home in a certain neighbourhood in the city, starting studies in a particular school and by getting a job in a certain workplace, and (2) the contextual effects people experience at these activity sites by being exposed to and interacting with others-with neighbours, schoolmates and co-workers. Both sorting and contextual effects are further shaped by the institutional set-up and spatial distribution of opportunities in different cities. For example, the way in which social housing is distributed across the urban neighbourhoods-being spatially clustered into certain neighbourhoods or spread evenly across the city-affects the residential sorting of less affluent households and, as a consequence, levels of segregation (Friesenecker \& Kazepov, 2021; Torpan et al., 2020).

The vicious circles of segregation framework thus argue that segregation experienced in one life domain tends to be reproduced in other life domains, and that segregation experienced early in life is often reproduced later in life and transmitted from parents to children because of the interconnected lives of the family members. Hence, when adding the time dimension, the vicious circles of segregation framework could be understood as a sequence of feedback loops both in space and time as people proceed over their life course, live their daily lives and navigate between home, school and workplaces, as well as leisure time activity sites and temporary mobility and activities abroad (Mooses,
Silm, Tammaru, \& Saluveer, 2020). Figure 2 illustrates how these sequences and feedback loops evolve over a person's life course and across generations, running from the lower-left corner to the upper-right corner. For adults, sorting in the labour and housing markets are connected. One the one hand, money buys choice on the housing market (Hulchanski, 2010), implying that the inequalities generated in the labour market drive inequalities in the housing market. On the other, the places where people live shape their labour market opportunities and access to jobs (Kain, 1968). The effects are not immediate, and there is often a time-lag before differences in the labour market become visible in the housing market (Tammaru, Marcińczak, Aunap, van Ham, \& Janssen, 2020).

The main global urban labour market trend is the professionalization of workforce as people living in large cities move up the occupational ladder because of significant improvements in education and skills (Hamnett, 2021; van Ham, Uesugi, Tammaru, Manley, \& Janssen, 2021). However, the spatial effects of professionalization are uneven as we can observe both professionalization, polarization and proletarianization taking place in residential neighbourhoods (Maloutas \& Botton, 2021). Professionalization of the urban workforce, and the residential preferences of higher-income households, has brought along three spatial "megatrends" related to residential segregation (Hochstenbach \& Musterd, 2018; see also Hess, Tammaru, \& van Ham, 2018; Tammaru et al., 2016; van Ham, Tammaru, et al., 2021):

1. The upgrade of the social composition of many neighbourhoods as the share of professionals increases in the city, often as a result of in situ changes as younger and better-educated people replace the less-educated previous generation;

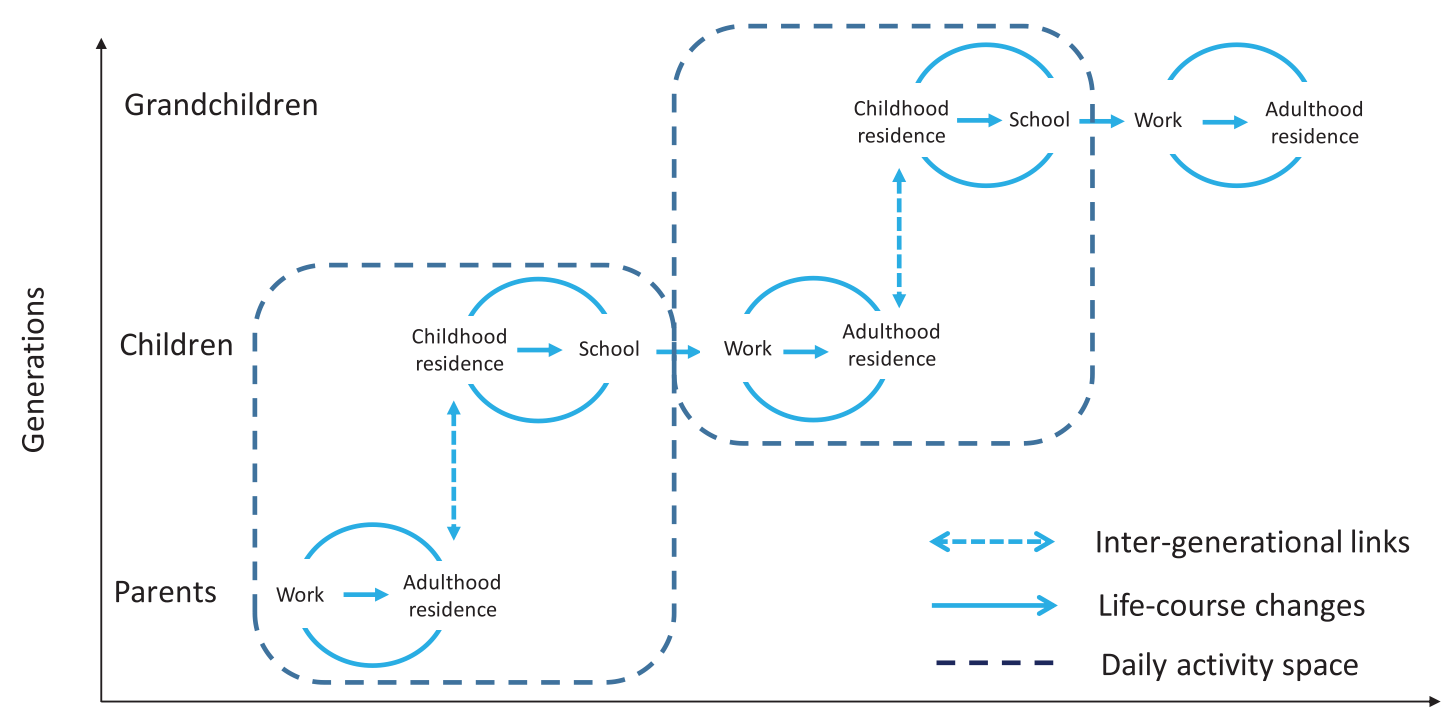

Linked lives of generations

Figure 2. The conceptual framework of vicious circles of segregation. 
2. Gentrification driven by the residential mobility of higher-income households moving into former working-class neighbourhoods, driving up housing prices in inner-city neighbourhoods;

3. The displacement of lower-income households to less-attractive suburban settings such as modernist high-rise housing estates.

It has been argued that residential neighbourhoods have lost their importance in producing and reproducing inequalities and segregation, since they are simply places where people sleep with very little social interaction occurring between neighbours (Boal, 1987). However, residential location has a wider meaning in peoples' lives beyond interacting with neighbours. The reputation of neighbourhoods itself is very important in residential decision-making (Bernelius et al., 2021). Housing is the key element that structures social and spatial inequalities in cities (Sorando, Uceda, \& Domínguez, 2021) and housing inequalities may be transmitted over several generations (Galster \& Wessel, 2019; Hedman \& van Ham, 2021). The location of homes shapes access to schools and jobs. As higher-income households have moved to inner cities and low-income households have moved the suburbs (Hochstenbach \& Musterd, 2018), a greater symmetry in the geography of where low-income and high-income households live and where high-wage and low-wage jobs are located has emerged (Delmelle et al., 2021). This implies that the geography of disadvantage is increasingly clustering on the peripheries of large cities (Hess et al., 2018).

The growing body of research using an activity space approach shows that the homes where people live are the main anchor points in daily activities and shape access, not only to schools and workplaces, but also a rich set of various leisure time activity sites (Järv, Ahas, \& Witlox, 2014; Silm \& Ahas, 2014). The importance of residential neighbourhoods as places of social interaction varies too between population groups. Neighbourhoods are central spatial settings for children, the elderly and members of the ethnic minority population (Wissink, Schwanen, \& van Kempen, 2016). For example, Hedman and van Ham (2021) show that, for $60 \%$ of people living in ethnic neighbourhoods, the neighbourhood is also the main daily activity site. Silm et al. (2018) show that segregation in the activity places (including leisure time sites) tends to be passed on to following generations.

Residential sorting of households with different incomes is thus directly related to a wider consideration set in terms of local amenities and public goods (Tiebout, 1956). Because of the linked lives of the family members, these considerations lead to the inter-generational transmission of segregation (Tammaru et al., 2017; van Ham et al., 2018). Children frequently attend a nearby school and, consequently, residential segregation of parents results in the school segregation of their children (Bernelius \& Vilkama, 2019; Oberti \& Savina, 2019). School segregation not only reflects existing pat- terns of residential segregation, but also plays a crucial role in maintaining and reinforcing social and spatial inequalities in cities (Boterman, Musterd, Pacchi, \& Ranci, 2019). Comparative studies of residential segregation and school segregation have shown that levels of school segregation tend to be higher than levels of residential segregation (S. Burgess, Wilson, \& Lupton, 2005). For example, having the opportunity to choose a school contributes to school segregation when affluent parents living in lower-income neighbourhoods send their kids to schools outside the home neighbourhood (E. Andersson, Malmberg, \& Östh, 2012; Maloutas \& Fujita, 2012; Maloutas \& Lobato, 2015). When school choice is not available or heavily restricted, parents may also start to 'shop' for schools by renting or buying homes in the catchment areas of desired schools (Rich et al., 2021).

In other words, school choice leads to school segregation through many and often highly localized mechanisms (Wilson \& Bridge, 2019), for example when affluent families prioritize the academic quality (Nieuwenhuis $\& X u, 2021$ ) and reputation (Bernelius et al., 2021) of the schools where their children study. School reputation, in turn, reinforces residential segregation, meaning that there is a circular relationship between residential segregation and school segregation (Rich et al., 2021; see Figure 2). This circularity emerges since differences in school quality affect residential segregation through prices in the housing market: Neighbourhoods in which schools are perceived as being of a higher quality attract higher-educated and affluent households, leading to higher property prices, which excludes low-income families (Nieuwenhuis \& Xu, 2021). In short, the interconnectedness of residential segregation and school segregation results from a joint residential-school choice, in parallel with the clustering of low-wage jobs and lowincome households in certain parts of cities. Residential clustering of high-income households into certain neighbourhoods contributes not only to school segregation, but also to broader inequalities in education. For many reasons, learning outcomes tend to be better in those neighbourhoods where more affluent families reside (Nieuwenhuis \& Hooimeijer, 2016; Owens \& Candipan, 2019; Rich et al., 2021).

\section{Policy Implications: A Roadmap to More Spatially Inclusive Cities}

Vicious circles of segregation are a result of the connectedness of social and spatial inequalities in different life domains. Advantage breeds advantage and disadvantage breeds disadvantage. Hence, policy interventions in one domain could potentially transmit into the other domains (Figure 1). Dealing with overall levels of income inequality is important for achieving more spatially inclusive cities. During times of growing income inequality, social and spatial mobility increase as well, leading to higher levels of segregation as higher income groups 
sort into more attractive neighbourhoods (Nieuwenhuis, Tammaru, van Ham, Hedman, \& Manley, 2020). When income inequality stays high, social and spatial inequalities remain high and intergenerational transmission of advantage and disadvantage becomes more frequent. While the growth of income inequalities leads to higher levels of spatial inequalities, the opposite is true as well: reduced income inequality contributes to lowering the levels of residential segregation (Tammaru et al., 2020).

Tackling the overlap between residential segregation and school segregation within the linked lives of family members is especially important for reducing spatial exclusion. Since children usually attend neighbourhood schools, urban policies that aim for diverse housing in residential neighbourhoods help to maintain socially diverse schools as well. The even distribution of social housing across urban neighbourhoods or allocation of social housing to different social groups helps to address residential segregation (Friesenecker \& Kazepov, 2021). If social housing is concentrated in certain neighbourhoods, as exemplified by modernist high-rise suburban housing estates (Hess et al., 2018), and residualized for lower-income groups (Ogrodowczyk \& Marcińczak, 2021), levels of segregation increase as well. Hence, lowering levels of residential segregation would be the first important measure that would help to reduce school segregation and differences in learning outcomes (Nieuwenhuis \& Xu, 2021). The second measure would relate to school choice; when parents have relatively unrestrained choice in which schools their kids learn, levels of school segregation rise as well as affluent parents compensate residential social mix with sending their kids to more attractive schools (E. Andersson et al., 2012; Maloutas \& Fujita, 2012; Maloutas \& Lobato, 2015; Maloutas, Spyrellis, Hadjiyanni, Capella, \& Valassi, $\&$ 2019). Bonding ties form at schools between the peers and lowering levels of school segregation would facilitate bridging social ties between different ethnic and social groups. For example, Lubbers, Van Der Werf, Kuyper, and Offringa (2006) find that peer acceptance in schools is not related to the socioeconomic characteristics of parents. Both skills and social networks are, in turn, important in the labour market (Muringani, Fitjar, \& Rodríguez-Pose, 2021).

The social interaction between neighbours is often less intense than the social interaction with peers at school and colleagues at work, giving rise to questions on the importance of neighbourhoods in shaping social interaction (Boal, 1987). However, Silm et al. (2021) demonstrate that the social networks are more diverse for people living in mixed neighbourhoods. Rahnu, Puur, Kleinepier, and Tammaru (2020) show that living in mixed neighbourhoods contributes to the formation of mixed-ethnic unions. Residential neighbourhoods shape social interactions directly and indirectly. First, sharing a neighbourhood may bring together neighbours with different backgrounds. For example, families living in the same neighbourhood may start to interact with each other if they have same-age children through meeting each other in the neighbourhood playground or when their children attend the same kindergarten or school (Špačková \& Ouředníček, 2012). The effect may also be indirect. Living in mixed neighbourhoods may make people more comfortable in diverse environments, leading to more social interactions with members of different social or ethnic groups in other life domains or even the formation of mixed-ethnic unions (Rahnu et al., 2020).

Policies aiming at residential mixing also need to go hand-in-hand with policies that address overall levels of income inequality, i.e., housing and labour market policies should reinforce each other in achieving higher levels of spatial inclusion. Otherwise, eliminating the transmission of disadvantage from one domain to another would be much harder. For example, Nieuwenhuis et al. (2017) find that adolescents whose parents move to a more affluent neighbourhood experience increased levels of depression, social phobia, aggression and conflict with parents. It is stressful for children if peers in the neighbourhood and school can afford significantly more. In short, city-level policies in residential mixing should go together with country-level policies on tackling overall levels of income inequalities in breaking vicious circles of segregation (cf. Tammaru et al., 2020; van Ham, Tammaru, et al., 2021). Likewise, a combination of residential mixing with parental choice in school allocation may not help to break the vicious circles of segregation, since higher-income households living in socially mixed neighbourhoods can opt for non-neighbourhood schools, increasing school segregation (cf. E. Andersson et al., 2012).

\section{Empirical Contribution: Main Findings from the Thematic Issue}

The most effective way of addressing the spatial underpinnings of social inequalities and segregation is to focus on residential neighbourhoods as related to other important life domains, as families live their linked lives and navigate from homes to schools and workplaces, as well as to leisure time activity sites. The rest of this thematic issue provides more detailed insights into the mechanisms of how segregation evolves in daily activity spaces, over the life course and between generations.

The first four articles deal with residential inequalities and housing. Friesenecker and Kazepov (2021) show that the unitary housing system in Vienna helps to keep levels of residential segregation low. Social housing is distributed relatively evenly in Vienna and the tenure structure in social housing is very mixed, preventing a rise in levels of residential segregation. Contrary to Vienna, social housing has contracted in Łódź, and is mainly occupied by lower-income households, a process called residualization of social housing (Ogrodowczyk \& Marcińczak, 2021). Since social housing is over-represented in certain parts of the city, its residualization contributes to increasing levels of residential segregation as well. 
Sorando et al. (2021) argue that housing is the key element of social inequality in Spain. Their study shows that gentrification has contributed to the disappearance of the last socially mixed residential settings in the inner city in Madrid. Immigrants are over-represented among lower-income households, and they are increasingly clustering in comparatively more affordable housing in the suburbs. Maloutas and Botton (2021) take a different angle by focussing on the role of changes in the occupational structure on residential geographies in Athens. Professionalization in the workforce is the main driving force at the level of the metropolitan area. However, they observe a more detailed geography of neighbourhood social trajectories characterized either by professionalization, proletarianization or polarization driven by both poles. Hedman and van Ham (2021) extend the analysis of residential change across three generations. They find that for Swedish women the probability of residential disadvantage or living in a low-income neighbourhood is correlated with the residential disadvantage of their mothers and, to some extent, their grandmothers.

The following two articles are about school domain. Nieuwenhuis and $\mathrm{Xu}$ (2021) demonstrate that there is a strong link between children from higher-income households attending wealthier schools in larger cities in Taiwan while no such link exists in smaller urban areas. Hence, wealthier and higher educated parents make use of opportunities when it comes to residential and school choice in the most urbanized areas to secure a better education for their children. Bernelius et al. (2021) find that school segregation and reputation are strongly linked to neighbourhood reputation in Helsinki. Schools with excellent institutional quality and high learning outcomes suffer from being in disadvantaged neighbourhoods with poor reputations. This implies that investments into quality education alone are not enough to break the vicious circle of segregation if parents' perceptions remain unchanged. However, successful ways in improving school reputation may lead to positive outcomes for the school and neighbourhood.

The following two articles focus on the work domain. Delmelle et al. (2021) focus on accessibility to jobs for people living in disadvantaged neighbourhoods in the suburbs of the Charlotte metropolitan area. They find that the suburbanization of both low-income households and low-wage jobs reinforce each other. Hence, improved access to jobs would not improve levels of employment among low-income households. However, improved accessibility to higher-wage jobs would increase incomes of people living in low-income neighbourhoods. Sorting in the labour market has, however, both a spatial (sorting into workplaces) and aspatial (sorting into industries) dimension. Sinitsyna, Torpan, Eamets, and Tammaru (2021) find that immigrants in Helsinki's labour market cluster both to certain workplaces, referred to as 'workplace segregation,' and certain industries, referred to as 'industrial niching.' Immigration policies favouring migrants with certain skill thus tend to increase inequalities in the labour market. Also, women are more likely than men to be employed simultaneously in segregated workplaces and niched industries.

The last two articles take an activity space approach to studying segregation in different life domains based on mobile phone data. Hedman, Kadarik, Andersson, and Östh (2021) analyse the daily mobility patterns of people living in two medium-sized cities in Sweden. Results reveal that daily mobility patterns are strongly segregated. People living in immigrant-dense neighbourhoods tend to spend most of their day in their home neighbourhood or, when they travel elsewhere to the city, the destination neighbourhoods tend to be immigrantdense too. People living in non-immigrant neighbourhood are more mobile, and their destination neighbourhoods tend to be less immigrant-dense. The findings from Silm et al. (2021) in Estonia are similar and the authors further elaborate that there is a relationship between spatial mobility and the ethnic composition of social networks. Neighbourhoods with a higher proportion of residents from another ethnic group tend to favour interethnic social networks. The activity-space is most constrained for ethnic minorities whose social networks contain mainly ethnic minorities, while the activity space is the largest for members of the ethnic majority population with mainly ethnic-majority-population social networks.

\section{The Way Forward: Five Questions Stemming from the Thematic Issue}

There is a paradigm shift taking place in research in spatial inequality and exclusion, from residential segregation to multi-domain understandings of segregation. This thematic issue outlines the conceptual foundations of the vicious circles of segregation to better understand the connectedness of segregation in different life domains and provide empirical insights to the various elements of the concept. It provides the basis for future research since many questions remain unanswered. We will highlight five questions that warrant future research.

First, what is the impact of improved education and the greater professionalization of workforces on social and spatial inequalities? There has been much interest in the role of income inequality on segregation. In parallel, there has been a heated debate on occupational composition change in cities by considering whether it is shifting towards higher levels of social polarization or professionalization. Recent empirical evidence indicates that professionalization has been a trend across the globe. Hence, although cities are more unequal on the one hand, the share of professionals earning high incomes is growing on the other. Furthermore, people worldwide increasingly concentrate in large cities. The expansion of people living and professionals working in large cities drives up house prices and pushes low-income households to urban peripheries. In this thematic issue, we learn that the professionalization of the workforce 
contributes to the socioeconomic upgrading of many urban neighbourhoods. However, more needs to be done when it comes to understanding the other effects of increased income inequality and professionalization of the workforce on cities. For example, does the socioeconomic upgrading of neighbourhoods also improve the reputation of the neighbourhoods, and what is its effect on breaking the vicious circles of segregation?

What are trajectories of segregation across neighbourhoods and individual life courses? In this thematic issue, we learn about segregation in daily activity spaces, the connectedness of segregation in different life domains and the transmission of segregation over multiple generations. However, we still know little about (1) neighbourhood trajectories and (2) individual life trajectories in different life domains, as well as how they are connected. Research in this thematic issue indicates that advantage and disadvantage tend to cluster increasingly to the broad macro regions in cities. Many innercity neighbourhoods gain high-income households, provide high-wage jobs and attractive schools. In many cities, inner cities that were the most socially mixed have become more homogenous as the number of highincome households increases. In contrast, many suburban locations have witnessed increased concentrations of low-wage jobs, low-income households and schools with poorer reputations. What such a spatial "scaling-up" of segregation into broader macro regions in the city means for individuals needs further research. In a nutshell, more longitudinal research is needed on neighbourhood and individual life trajectories. For example, research could address how family or residential contexts are related to the educational trajectories of people through their whole school life from kindergarten to graduating from university, and how these educational trajectories with their various episodes and twists, in turn, shape different aspects of labour market success for individuals.

In this thematic issue, we learn that the residential outcomes of daughters, mothers and grandmothers are related. However, we lack nuance of exactly how the lives of family members are related to each other regarding the intergenerational transmission of spatial inequalities. This begs the question: What is the role of linked lives of family members in the transmission of spatial inequality? For example, how do the high and increasing levels of wealth inequality contribute the intergenerational transmission of various resources and capital? And from a different but equally important note: Do different family arrangements matter in segregation? Families in contemporary cities take different forms and shapes and are in constant flux; families form and dissolve, and kids grow up in very diverse family arrangements. What is the role of increased transnationalisation in everyday lives? Although research in this thematic issue shows that many people live very localized and neighbourhoodbased lives, there is also a growing number of families where one of the partners works abroad or under- takes long-distance commutes within the home country. Likewise, many people living in large cities have second homes which they visit in summertime. Kids spend more time outdoors in summertime and may develop friendships with kids in very different social and spatial environments in second-home neighbourhoods compared to their first-home neighbourhoods.

What is the role of social networks and digital spaces in shaping inequality and inclusion in physical spaces? Although research in this thematic issue demonstrates the continued importance of neighbourhoods in structuring the lives of families, it also shows that spatial mobility and social networks are mutually related to each other. Also, an important part of social relations takes place in the digital space, where people make friends and find partners. Many digital environments and services are location-based, though. For example, people search for partners on digital platforms that allow filtering according to proximity. It is, therefore, important to learn more about whether the social homophily in digital spaces helps to reduce the tyranny of space, by bringing together people with similar interests irrespective of their social background, or reinforces segregation in the physical space as well.

Finally, how do the aims of smart and sustainable cities shape segregation and inclusion? The leading paradigms in urban research relate to smart, sustainable and inclusive cities. Future cities aim to be green and sustainable and, for this end, reducing the ecological footprint of mobility is a key target. It implies promoting green and active forms of mobility, including public transit, walking and cycling. Research is needed on the implications of increased active mobility on the sizes of people's activity spaces and whether shorter travel distances contribute to the spatial isolation of social groups who reside in different neighbourhoods of the city.

\section{Acknowledgments}

Working on this thematic issue was a great pleasure because of the high quality of the contributions and the smooth writing process, for which we are indebted to all authors. The support from the editorial staff at Social Inclusion was a key to success; the quality of the reviews was high, and the speed and efficiency in handling the review process was excellent. We are also very grateful to the Estonian Research Agency, who has provided financial support to the five-year PRG306 project "Understanding the Vicious Circles of Segregation. A Geographic Perspective" (for more see www.segregationcircles.eu), as well as to the support of the Infotechnological Mobility Observatory (www.imo.ut.ee/en) and the EU Horizon project "UpLift" (www.uplift-youth.eu).

\section{References}

Andersson, E., Malmberg, B., \& Östh, J. (2012). Travelto-school distances in Sweden 2000-2006: Changing 
school geography with equality implications. Journal of Transport Geography, 23, 35-43. https://doi.org/ 10.1016/j.jtrangeo.2012.03.022

Andersson, R., \& Kährik, A. (2016). Widening gaps segregation dynamics during two decades of economic and institutional change in Stockholm. In T. Tammaru, S. Marcińczak, M. van Ham, \& S. Musterd (Eds.), Socio-economic segregation in European capital cities: East meets West (pp. 110-131). London: Routledge.

Bernelius, V., \& Vilkama, K. (2019). Pupils on the move: School catchment area segregation and residential mobility of urban families. Urban Studies, 56(15), 3095-3116. https://doi.org/10.1177/00420980198 48999

Bernelius, V., Huilla, H., \& Lobato, I. R. (2021). 'Notorious schools' in 'notorious places'? Exploring the connectedness of urban and educational segregation. Social Inclusion, 9(2), 154-165.

Boal, F. W. (1987). Segregation. In M. Pacione (Ed.), Socail geography: Progress and prospect (pp. 90-128). London: Croom Helm.

Booth, C. (1888). Condition and occupations of the people of East London and Hackney, 1887. Journal of the Royal Statistical Society, 51(2), 276-339. https:// doi.org/10.2307/2979109

Boterman, W., \& Musterd, S. (2017). Differentiated residential orientations of class fractions. In SAGE handbook of new urban studies (pp. 388-407). Thousand Oaks, CA: SAGE Publications. https://doi.org/ 10.4135/9781412912655.n25

Boterman, W., Musterd, S., Pacchi, C., \& Ranci, C. (2019). School segregation in contemporary cities: Sociospatial dynamics, institutional context and urban outcomes. Urban Studies, 56(15), 3055-3073. https:// doi.org/10.1177/0042098019868377

Burgess, E. W. (1925). Residential segregation in American cities. The Annals of the American Academy of Political and Social Science, 140, 105-115. https:// www.jstor.org/stable/1016838

Burgess, S., Wilson, D., \& Lupton, R. (2005). Parallel Lives? Ethnic segregation in schools and neighbourhoods. Urban Studies, 42(7), 1027-1056. https://doi. org/10.1080/00420980500120741

Coulter, R., van Ham, M., \& Findlay, A. (2015). Rethinking residential mobility: Linking lives through time and space. Progress in Human Geography, 49(3), 334-351. https://doi.org/10.1177/0309132515575 417

Delmelle, E., Nilsson, I., \& Adu, P. (2021). Poverty suburbanization, job accessibility, and employment outcomes. Social Inclusion, 9(2), 166-178.

Ellis, M., Wright, R., \& Parks, V. (2004). Work together, live apart? Geographies of racial and ethnic segregation at home and at work. Annals of the Association of American Geographers, 94(3), 620-637. https:// doi.org/10.1111/j.1467-8306.2004.00417

Friesenecker, M., \& Kazepov, Y. (2021). Housing Vienna:
The socio-spatial effects of inclusionary and exclusionary mechanisms of housing provision. Social Inclusion, 9(2), 77-90.

Galster, G., \& Wessel, T. (2019). Reproduction of social inequality through housing: A three-generational study from Norway. Social Science Research, 78, 119-136. https://doi.org/10.1016/j.ssresearch.2018. 12.016

Gonalons-Pons, P., \& Schwartz, C. R. (2017). Trends in economic homogamy: Changes in assortative mating or the division of labor in marriage? Demography, 54(3), 985-1005. https://doi.org/10.1007/s13524017-0576-0

Hamnett, C. (2021). The changing social structure of global cities: Professionalisation, proletarianisation or polarisation. Urban Studies, 58(5), 1050-1066. https://doi.org/10.1177/0042098020940556

Hedman, L., \& van Ham, M. (2021). Three generations of intergenerational transmission of neighbourhood context. Social Inclusion, 9(2), 129-141.

Hedman, L., Kadarik, K., Andersson, R., \& Östh, J. (2021). Daily mobility patterns: Reducing or reproducing inequalities and segregation? Social Inclusion, 9(2), 208-221.

Hess, D. B., Tammaru, T., van Ham, M. (2018). Housing estates in Europe: Poverty, ethnic segregation and policy challenges. Berlin: Springer. https://doi.org/ 10.1007/978-3-319-92813-5

Hochstenbach, C., \& Musterd, S. (2018). Gentrification and the suburbanization of poverty: Changing urban geographies through boom and bust periods. Urban Geography, 39(1), 26-53. https://doi.org/10.1080/ 02723638.2016 .1276718

Hulchanski, D. (2010). The three cities within Toronto: Income polarization among Toronto's neighbourhoods, 1970-2005. Toronto: University of Toronto.

Järv, O., Ahas, R., \& Witlox, F. (2014). Understanding monthly variability in human activity spaces: A twelve-month study using mobile phone call detail records. Transportation Research Part C: Emerging Technologies, 38, 122-135. https://doi.org/10.1016/ j.trc.2013.11.003

Järv, O., Müürisepp, K., Ahas, R., Derudder, B., \& Witlox, F. (2015). Ethnic differences in activity spaces as a characteristic of segregation: A study based on mobile phone usage in Tallinn, Estonia. Urban Studies, 52(14), 2680-2698. https://doi.org/ 10.1177/0042098014550459

Kain, J. F. (1968). Housing segregation, negro employment, and metropolitan decentralization. The Quarterly Journal of Economics, 82(2). https://doi.org/ $10.2307 / 1885893$

Kalmijn, M. (1991). Status homogamy in the United States. American Journal of Sociology, 97(2), 496-523. https://doi.org/10.1086/229786

Krysan, M., \& Crowder, K. (2017). Cycle of segregation: Social processes and residential stratification. New York, NY: Russell Sage Foundation. 
Kukk, K., van Ham, M., \& Tammaru, T. (2019). EthniCity of leisure: A domains approach to ethnic integration during free time activities. Tijdschrift voor Economische en Sociale Geografie, 110(3), 289-302. https:// doi.org/10.1111/tesg.12307

Lubbers, M. J., Van Der Werf, M. P. C., Kuyper, H., \& Offringa, G. J. (2006). Predicting peer acceptance in Dutch youth: A multilevel analysis. Journal of Early Adolescence, 26(1), 4-35. https://doi.org/10.1177/ 0272431605282747

Maloutas, T., \& Botton, H. (2021). Trends of social polarisation and segregation in Athens (1991-2011). Social Inclusion, 9(2), 117-128.

Maloutas, T., \& Fujita, K. (Eds.). (2012). Residential segregation in comparative perspective. Making sense of contextual diversity. Farnham: Ashgate.

Maloutas, T., \& Lobato, I. R. (2015). Education and social reproduction: Educational mechanisms and residential segregation in Athens and Dortmund. Local Economy, 30(7), 800-817. https://doi.org/10.1177/ 0269094215601817

Maloutas, T., Spyrellis, S., Hadjiyanni, A., Capella, A., \& Valassi, D. (2019). Residential and school segregation as parameters of educational performance in Athens. Cybergeo: European Journal of Geography. https:// doi.org/10.4000/cybergeo.33085

Manley, D., van Ham, M., \& Hedman, L. (2020). Inherited and spatial disadvantages: A longitudinal study of early adult neighborhood careers of siblings. Annals of the American Association of Geographers, 110(6), 1670-1689. https://doi.org/10.1080/ 24694452.2020.1747970

Mooses, V., Silm, S., \& Ahas, R. (2016). Ethnic segregation during public and national holidays: A study using mobile phone data. Geografiska Annaler, Series B: Human Geography, 98(3), 205-219. https://doi.org/ 10.1111/geob.12100

Mooses, V., Silm, S., Tammaru, T., \& Saluveer, E. (2020). An ethno-linguistic dimension in transnational activity space measured with mobile phone data. Humanities and Social Sciences Communications, 7(1), 1-13. https://doi.org/10.1057/s41599-020-00627-3

Muringani, J., Fitjar, R. D., \& Rodríguez-Pose, A. (2021). Social capital and economic growth in the regions of Europe. Environment and Planning A: Economy and Space. Advance online publication. https://doi.org/ 10.1177/0308518X211000059

Musterd, S. (2005). Social and ethnic segregation in Europe: Levels, causes and effects. Journal of Urban Affairs, 27(3), 331-348. https://doi.org/10.1111/ j.0735-2166.2005.00239.x

Musterd, S., \& Ostendorf, W. (1998). Urban segregation and the welfare state inequality and exclusion in Western cities. London: Routledge. https://doi.org/ $10.4324 / 9780203448533$

Musterd, S., Ostendorf, W., \& de Vos, S. (2003). Neighbourhood effects and social mobility: A longitudinal analysis. Housing Studies, 18(6), 877-892. https:// doi.org/10.1080/0267303032000135483

Nieuwenhuis, J., \& Hooimeijer, P. (2016). The association between neighbourhoods and educational achievement, a systematic review and meta-analysis. Journal of Housing and the Built Environment, 31(2), 321-347. https://doi.org/10.1007/s10901-0159460-7

Nieuwenhuis, J., Tammaru, T., van Ham, M., Hedman, L., \& Manley, D. (2020). Does segregation reduce socio-spatial mobility? Evidence from four European countries with different inequality and segregation contexts. Urban Studies, 57(1), 176-197. https://doi. org/10.1177/0042098018807628

Nieuwenhuis, J., van Ham, M., Yu, R., Branje, S., Meeus, W., \& Hooimeijer, P. (2017). Being poorer than the rest of the neighborhood: Relative deprivation and problem behavior of youth. Journal of Youth and Adolescence, 46(9), 1891-1904. https://doi.org/ 10.1007/s10964-017-0668-6

Nieuwenhuis, J., \& Xu, J. (2021). Residential segregation and unequal access to schools. Social Inclusion, 9(2), 142-153.

Oberti, M., \& Savina, Y. (2019). Urban and school segregation in Paris. The complexity of contextual effects on school achievement: The case of middle schools in the Paris metropolitan area. Urban Studies, 56(15), 3117-3142. https://doi.org/10.1177/ 0042098018811733

Ogrodowczyk, A., \& Marcińczak, S. (2021). Pending final version. Social Inclusion, 9(2), 91-103.

Owens, A., \& Candipan, J. (2019). Social and spatial inequalities of educational opportunity: A portrait of schools serving high- and low-income neighbourhoods in US metropolitan areas. Urban Studies, 56(15), 3178-3197. https://doi.org/10.1177/ 0042098018815049

Park, Y. M., \& Kwan, M. P. (2017). Individual exposure estimates may be erroneous when spatiotemporal variability of air pollution and human mobility are ignored. Health and Place, 43, 85-94. https://doi. org/10.1016/j.healthplace.2016.10.002

Pastak, I. (2021). Gentrification and displacement in postindustrial neighbourhoods of Tallinn. Tartu: University of Tartu Press.

Peach, C. (1980). Ethnic segregation and intermarriage. Annals of the Association of American Geographers, 70(3), 371-381. https://doi.org/10.1111/ j.1467-8306.1980.tb01320.x

Peach, C. (1996). Good segregation, bad segregation. Planning Perspectives, 11(4), 379-398.

Rahnu, L., Puur, A., Kleinepier, T., \& Tammaru, T. (2020). The role of neighbourhood and workplace ethnic contexts in the formation of inter-ethnic partnerships: A native majority perspective. European Journal of Population, 36, 247-276. https://doi.org/10.1007/ s10680-019-09528-x

Rich, P., Candipan, J., \& Owens, A. (2021). Segregated neighborhoods, segregated schools: Do charters 
break a stubborn link? Demography, 58(2), 471-498. https://doi.org/10.1215/00703370-9000820

Rivkin, S. G. (1994). Residential segregation and school integration. Sociology of Education, 67(4), 279-292. https://doi.org/10.2307/2112817

Rossi, P. H. (1955). Why families move: A study in the social psychology of urban residential mobility. London: Free Press.

Schelling, T. C. (1971). Dynamic models of segregation. The Journal of Mathematical Sociology, 1(2), 143-186. https://doi.org/10.1080/0022250X.1971. 9989794

Silm, S., \& Ahas, R. (2014). Ethnic differences in activity spaces: A study of out-of-home nonemployment activities with mobile phone data. Annals of the Association of American Geographers, 104(3), 542-559. https://doi.org/10.1080/00045608.2014.892362

Silm, S., Ahas, R., \& Mooses, V. (2018). Are younger age groups less segregated? Measuring ethnic segregation in activity spaces using mobile phone data. Journal of Ethnic and Migration Studies, 44(11), 17971817. https://doi.org/10.1080/1369183X.2017. 1400425

Silm, S., Mooses, V., Puura, A., Masso, A., Tominga, A., \& Saluveer, E. (2021). The relationship between ethnolinguistic composition of social networks and activity space: A study using mobile phone data. Social Inclusion, 9(2), 192-207.

Sinitsyna, A., Torpan, K., Eamets, R., \& Tammaru, T. (2021). Overlap between industrial niching and workplace segregation: Role of immigration policy, culture and country of origin. Social Inclusion, 9(2), 179-191.

Sorando, D., Uceda, P., \& Domínguez, M. (2021). Inequality on the increase: Trajectories of privilege and inequality in Madrid. Social Inclusion, 9(2), 104-116.

Špačková, P., \& Ouředníček, M. (2012). Spinning the web: New social contacts of Prague's suburbanites. Cities, 29(5), 341-349. https://doi.org/10.1016/ j.cities.2011.09.002

Strömgren, M., Tammaru, T., Danzer, A. M., van Ham, M., Marcińczak, S., Stjernström, O., \& Lindgren, U. (2014). Factors shaping workplace segregation between natives and immigrants. Demography, 51(2), 645-671. https://doi.org/10.1007/s13524-0130271-8

Tammaru, T., Kallas, K., \& Eamets, R. (Eds.). (2017). Estonian human development report: Estonia at the age of migration. Tallinn: Eesti Koostöö Kogu.

Tammaru, T., Marcińczak, S., Aunap, R., van Ham, M., \& Janssen, H. (2020). Relationship between income inequality and residential segregation of socioeconomic groups. Regional Studies, 54(4), 450-461. https://doi.org/10.1080/00343404.2018.1540035

Tammaru, T., Strömgren, M., Stjernström, O., \& Lindgren,
U. (2010). Learning through contact? The effects on earnings of immigrant exposure to the native population. Environment and Planning A, 42(12), 2938-2955. https://doi.org/10.1068/a4396

Tammaru, T., van Ham, M., Marcińczak, S., \& Musterd, S. (Eds.). (2016). Socio-economic segregation in European capital cities: East meets West. London: Routledge. https://doi.org/10.4324/9781315758879

Tiebout, C. M. (1956). A pure theory of local expenditures. Journal of Political Economy, 64(5), 416-424. https://doi.org/10.1086/257839

Toomet, O., Silm, S., Saluveer, E., Ahas, R., \& Tammaru, T. (2015). Where do ethno-linguistic groups meet? How copresence during free-time is related to copresence at home and at work. PlosOne, 10(5). https://doi.org/ 10.1371/journal.pone.0126093

Torpan, K., Sinitsyna, A., Kährik, A., Kauppinen, T. M., \& Tammaru, T. (2020). Overlap of migrants' housing and neighbourhood mobility. Housing Studies. Advance online publication. https://doi.org/ 10.1080/02673037.2020.1849574

van Ham, M., \& Tammaru, T. (2016). New perspectives on ethnic segregation over time and space. A domains approach. Urban Geography, 37(7), 953-962. https://doi.org/10.1080/02723638.2016. 1142152

van Ham, M., Tammaru, T., \& Janssen, H. J. (2018). A multi-level model of vicious circles of socio-economic segregation. In OECD (Eds.), Divided cities: Understanding intra-urban disparities (pp. 135-154). Paris: OECD. https://doi.org/10.1787/9789264300385-en

van Ham, M., Tammaru, T., Ubarevičienè, R., \& Janssen, H. (Eds.). (2021). Urban socio-economic segregation and income inequality: A global perspective. Berlin: Springer. https://doi.org/10.1007/978-3-03064569-4

van Ham, M., Uesugi, M., Tammaru, T., Manley, D., \& Janssen, H. (2021). Changing occupational structures and residential segregation in New York, London and Tokyo. Nature Human Behaviour, 4(11), 1124-1134. https://doi.org/10.1038/s41562-020-0927-5

Vogiazides, L., \& Chihaya, G. K. (2020). Migrants' longterm residential trajectories in Sweden: Persistent neighbourhood deprivation or spatial assimilation? Housing Studies, 35(5), 875-902. https://doi.org/ 10.1080/02673037.2019.1636937

Wilson, D., \& Bridge, G. (2019). School choice and the city: Geographies of allocation and segregation. Urban Studies, 56(15), 3198-3215. https://doi.org/ 10.1177/0042098019843481

Wissink, B., Schwanen, T., \& van Kempen, R. (2016). Beyond residential segregation: Introduction. Cities, 59, 126-130. https://doi.org/10.1016/j.cities.2016. 08.010 


\section{About the Authors}

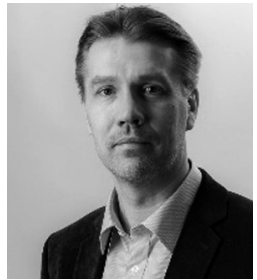

Tiit Tammaru is Professor of Urban and Population Geography and Head of the Chair of Human Geography at the University of Tartu. He is also a member of the Estonian Academy of Sciences. His research interests include migration, residential mobility, housing, relations between social inequalities and socioeconomic segregation, as well as comparative segregation studies. He is developing the concept of 'vicious circles of segregation' to understand segregation across different life domains.

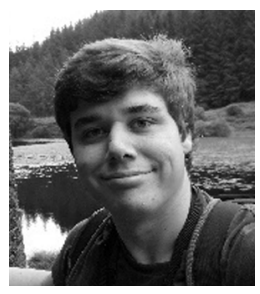

David Knapp is a PhD candidate in the Department of Geography at the University of Tartu. His PhD research focuses on the relationship between residential segregation and school segregation. Other research interests of his include sustainable urban planning and age-related segregation.

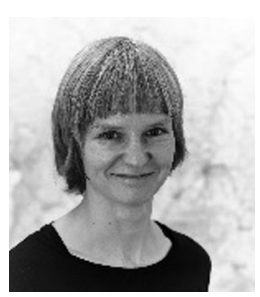

Siiri Silm is an Associate Professor in Human Geography and acting Head of the Mobility Lab at the University of Tartu. She has developed mobile phone-based methodology (passive mobile positioning, smartphone-based positioning) and has been conducting related research since 2004 . Her main fields of research include human mobility, analyses of urban space, socio-ethnic inequalities, social networks and cross-border mobility. She acts as the Head of the organizing committee of Mobile Tartu conferences.

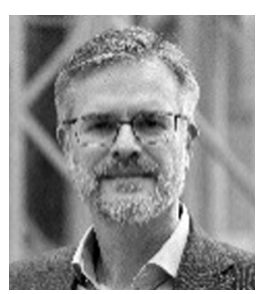

Maarten van Ham is Professor of Urban Geography and Head of the Department of Urbanism at Delft University of Technology. He is a population geographer with a background in economic and urban geography. He is a Research Fellow at IZA and Professor of Geography at the University of St Andrews. In 2014, Maarten was awarded a two-million-euro ERC Consolidator Grant for a 5-year research project on neighbourhood effects (DEPRIVEDHOODS).

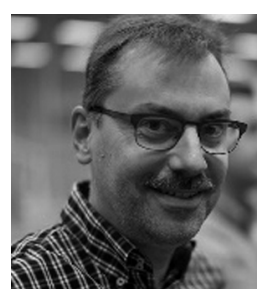

Frank Witlox is Senior Full Professor of Economic Geography and Head of the Department of Geography at Ghent University. He is also Visiting Professor at the Department of Geography, University of Tartu. His research focuses mainly on travel behaviour analysis and modelling. He is the current Editor-in-Chief of the Journal of Transport Geography, a world-leading interdisciplinary journal focusing on the geographical dimensions of transport, travel and mobility. In recognition to the field, he received two honorary doctorates, one in 2018 from the University of Tartu (Estonia) and one in 2020 from the Odessa National Polytechnic University (Ukraine). 